\title{
Seasonal variations in metal content of two Unio pictorum mancus (Mollusca, Unionidae) populations from two lakes of different trophic state
}

\author{
Oscar RAVERA*, Gian Maria BEONE ${ }^{1)}$, Pier Renato TRINCHERINI ${ }^{2)}$ and Nicoletta RICCARDI \\ CNR - Institute of Ecosystem Study, Largo Tonolli 50, 28922 Verbania Pallanza, Italy \\ ${ }^{1)}$ Università Cattolica del Sacro Cuore, Istituto di Chimica Agraria e Ambientale, Via E. Parmense 84, 29100 Piacenza, Italy \\ ${ }^{2)}$ LIMS (Lab. of Inorganic Mass Spectrometry), ITI "L. Cobianchi" and Dipartimento di Chimica, Università di Torino, Piazza \\ Martiri di Trarego 8, 28921 Verbania, Italy \\ *e-mail corresponding author: o.ravera@ise.cnr.it
}

\begin{abstract}
To assess the impact of lake trophy on trace element accumulation by Unio pictorum mancus, a population from the mesooligotrophic Lake Maggiore was compared with a population from the eutrophic Lake Candia. The element content in soft tissue and shell biomass, the seasonal variations of element concentrations in soft tissues and shell, and the relationship between element concentrations in the water and those in the tissues were estimated in pursuit of this objective. Thirteen mussel samplings were performed in Lake Maggiore between May 2003 and September 2004 and in Lake Candia between June 2003 and August 2004. Filtered water samples were collected seasonally. Water, shell and soft tissue samples were analysed by ICP-OES and ICP-MS for the measurement of following elements: $\mathrm{Zn}, \mathrm{Cu}, \mathrm{Fe}, \mathrm{Mn}, \mathrm{Ni}, \mathrm{As}, \mathrm{Pb}, \mathrm{Co}, \mathrm{Cr}, \mathrm{Mo}, \mathrm{V}, \mathrm{Cd}, \mathrm{Be}$ and $\mathrm{Ca}$. The element concentrations in the mussel tissues and shell from Lake Maggiore were higher than those from Lake Candia. Due to the higher population density and higher element concentrations in the mussels of Lake Maggiore, the element content in the biomass per $m^{2}$ in this lake far exceeded that in Lake Candia. The element concentrations in the mussel tissues, but not in their shells, of both lakes showed a seasonal pattern of variation; this was to be expected as a result of the slower turnover time of the elements in the shell than in the tissues. For all the elements, except Mo, Cr and Be, the "concentration factor" (C.F.) value was higher in Lake Maggiore than in Lake Candia mussels, ranging from 10 to $10^{4}$ and 10 to $10^{3}$ respectively. The higher concentrations in the mussel tissues from Lake Maggiore were justified not merely by the higher element concentrations in the lake water, but probably also because other causes, such as element concentrations in food and element abundance in available forms, combine to affect the concentrations of the elements in the tissues.
\end{abstract}

Key words: freshwater bivalve, seasonal variations, metals, shell, soft tissues, concentration factor

\section{INTRODUCTION}

The great capacity of bivalves to concentrate various toxic and non-toxic trace elements in their bodies with no evident danger to themselves is often exploited to identify pollutants in an environment, including those in which the pollutants are so diluted that they cannot be analyzed by the methods commonly used (e.g., Merlini et al. 1965; Ferrington et al. 1983; Doherty et al. 1993; Oertel 1998; Ravera et al. 2003a). As an example, radiomanganese (Mn-54) from the fall-out of nuclear tests in the Pacific area was detected for the first time in Europe by gamma spectrometry in Unio pictorum from Lake Maggiore (Ravera \& Vido 1961; Gaglione \& Ravera 1964). Besides having great accumulation capacity and low discrimination power (Bryan 1979), bivalves are regarded as useful pollutant indicators because of their wide geographical distribution, the presence of adults in all seasons and their sedentary way of life. In addition, they can easily be sampled and several species can live in both clean and polluted water bodies.

The shell and soft tissues composing the mussel body typically differ in their chemical composition, and the turnover time of the same element is much shorter in the tissues than in the shell. Consequently, the chemical composition of the tissues is a reflection of the recent situation of the environment, while the shell composition reflects the integrated situation over a time period corresponding to the age of the mussels. Since several mussel species have a life span of many years (e.g., up to 200 years for Margaritifera margaritifera), the variations over time of some environmental characteristics (e.g., nutrient enrichment, $\mathrm{pH}$ lowering, temperature variations, metal concentration) have been recorded through shell analyses (Mutvei \& Westermark 2001; Price \& Pearce 1997; Lazareth et al. 2003).

Mussels can play an important role in the environments where they are very abundant (Dame et al. 2002), particularly because of their influence on biogeochemical cycles. For example, the shells are a reserve of calcium carbonate and associated elements (e.g., strontium) which, when the mussel dies, are dissolved in soft water environments in a relatively short time, while in hard water they are preserved for a long time and may give rise to thanatocoenosis. During the mussel's life, there is a continuous flux of elements from the environment (water and food) to the tissues and vice versa. When a mussel dies, its tissues become available as food for other organisms or decompose in a relatively 
short time. Thus in the former case the trace elements are transferred from the mussel tissues to other organisms, in the latter the elements are released to the water. In evaluating the importance of mussels in biogeochemical cycles, the first step is to quantify the element content in the shell and tissue biomasses. There is a huge amount of information on the concentration of a number of elements in marine and freshwater mussels, but the available information on the element contents in their biomass is unfortunately poor.

The present study, dealing with 13 trace elements (Mn, Fe, Zn, Cu, Pb, Ni, Cr, Cd, Co, V, Be, Mo, As) plus calcium measured in mussels (shell and soft tissues) and filtered water from Lake Maggiore and Lake Candia, had three major aims.

The first was to compare element contents in the shell and soft tissue biomass of two Unio pictorum mancus populations: one from the oligo-mesotrophic Lake Maggiore, the other from the eutrophic Lake Candia.

The second aim was to compare seasonal variations of element concentrations in the mussel shell and tissues of both populations and to estimate the annual mean concentration of each element and its variability. In addition, the similarity level of the seasonal variations of the elements in the mussel tissues was tested.

Thirdly, since mussels are commonly used in biomonitoring surveys as accumulator organisms, we wanted to evaluate the relationship between element concentrations in mussel soft tissues and those in the water of the two lakes.

\section{MATERIAL AND METHODS}

\subsection{Study sites}

The study was carried out on individuals of Unio pictorum mancus (Bivalve, Unionidae) from the deep meso-oligotrophic Lake Maggiore and the other from the shallow eutrophic Lake Candia, respectively (Tab. 1). One sampling station (at a place called Sabbie d'Oro) was located on the south-eastern side of Lake Maggiore (latitude N 4550'19", longitude E $\left.8^{\circ} 37^{\prime} 17^{\prime \prime}\right)$ near the village of Brebbia (Province of Varese). The station is a gently sloping bay with silty-muddy sediments. The other station, on the south-eastern side of Lake Candia (latitude N 4519'32", longitude E 7०54'38", Province of Turin), was located in the littoral zone, also gently sloping, with sediments made up of mud, silt and sand. Further details are reported in another paper (Ravera et al. 2007, this issue).

\subsection{Sampling and sample preparation}

Six mussels from each sample collected monthly from the two lakes for a population biology study (Ravera et al. 2007) were used to analyse 13 trace elements and $\mathrm{Ca}$ concentration in the soft tissues and shell. The mussels were chosen at random within a shell length range from 64 to $71 \mathrm{~mm}$. This size was preferred because specimens of this size were abundant in both lakes. The mussel shells were carefully cleaned by scrubbing the surface with a nylon nailbrush to eliminate sediment particles and periphyton coating the periostracum, and to remove attached zebra mussels (Dreissena polymorpha).

Tab. 1. Morphometric parameters of Lake Maggiore (Ambrosetti et al. 1992) and Lake Candia (Giussani \& Galanti 1992).

\begin{tabular}{lcc}
\hline & Lake Maggiore & Lake Candia \\
\hline Mean lake level (m a.s.l.) & 194 & 226 \\
Watershed area $\left(\mathrm{km}^{2}\right)$ & 6599 & 9.9 \\
Lake area $\left(\mathrm{km}^{2}\right)$ & 212.5 & 1.5 \\
Mean depth $(\mathrm{m})$ & 177 & 3.8 \\
Maximum depth (m) & 370 & 7.7 \\
\hline
\end{tabular}

The cleaned mussels were preserved in plastic bags placed in an icebox and brought to the laboratory where they were kept at $-20{ }^{\circ} \mathrm{C}$ until analysis. After separation of the soft tissues from their shell, tissues and shells of the six mussels were separately pooled to obtain two sub-samples each. The soft tissues were freeze-dried and then kept at $40{ }^{\circ} \mathrm{C}$ for 24 hours before pulverisation in a Planetary Micro Mill Fritsch (Fritsch GmbH, IdarOberstein, Germany) Pulverisette 7 model with jars and balls in agate. The shells were broken into several pieces to facilitate pulverisation. The powder obtained was passed through a sieve with $0.2 \mathrm{~mm}$ opening size. The samples of shells and soft tissues were mineralised by a Microwave Digestion System CEM (Matthews, NC, USA) MDS-2000 model, with an operating frequency of $2450 \mathrm{MHz}$ and a maximum power of 620 W. Prior to each digestion, the teflon PFA vessels were washed with $2 \mathrm{~mL}$ of hot concentrated nitric acid (heated for $10 \mathrm{~min}$ at $620 \mathrm{~W}$ ) and then thoroughly rinsed with deionized water. About $500 \mathrm{mg}$ of sample, $8 \mathrm{~mL}$ of $\mathrm{HNO}_{3}(65 \% \mathrm{~m} / \mathrm{v})$, and $1 \mathrm{~mL}$ of $\mathrm{H}_{2} \mathrm{O}_{2}(30 \% \mathrm{~m} / \mathrm{v})$ were transferred into microwave vessels and left in contact for two hours. Each time, six samples were placed in the microwave carousel, together with a blank prepared with suprapure reagents, and were submitted to the following heating program: $5 \mathrm{~min}$ at $40 \%$ power; $5 \mathrm{~min}$ at $60 \%$ power; $15 \mathrm{~min} 80 \%$ power; last cooling. All these solutions were transferred and filtered (Whatman $\mathrm{n}^{\circ}$ 42) into a $50 \mathrm{~mL}$ flask and brought to volume. A certified mussel tissue, reference sample CRM 278 (Mytilus edulis), prepared by the Community Bureau of Reference (BCR) was used as reference material to evaluate the accuracy of the analytical procedure (Tab. 2).

Water samples were collected seasonally from each lake: 10 double samples from Lake Maggiore and 7 from Lake Candia. Soon after collection the samples were filtered on a $0.45 \mu \mathrm{m}$ (pore size) Millipore filter and preserved in plastic bottles by the addition of a few drops of $65 \%(\mathrm{w} / \mathrm{v})$ nitric acid. 
Tab. 2. Determination of metals in BCR (Community Bureau of Reference) mussel tissue CRM 278; values found are means of 4 replicates \pm SD. *: Means of 3 replicates $\pm \mathrm{SD}$; values in brackets are reported by $\mathrm{BCR}$ and are indicative only.

\begin{tabular}{lcc}
\hline Element & Found $\left(\mu \mathrm{g} \mathrm{g}^{-1}\right)$ & Certified $\left(\mu \mathrm{g} \mathrm{g}^{-1}\right)$ \\
\hline $\mathrm{Al}$ & $37 \pm 8$ & $(70)$ \\
$\mathrm{As}^{*}$ & $5.88 \pm 0.08$ & $5.9 \pm 0.2$ \\
$\mathrm{Be}^{*}$ & 0.06 & \\
$\mathrm{Ca}$ & $934 \pm 48$ & $(1000)$ \\
$\mathrm{Cd}$ & $0.335 \pm 0.007$ & $0.34 \pm 0.02$ \\
$\mathrm{Co}^{*}$ & $0.35 \pm 0.01$ & $(0.34)$ \\
$\mathrm{Cr}$ & $0.83 \pm 0.1$ & $0.80 \pm 0.08$ \\
$\mathrm{Cu}$ & $9.07 \pm 0.42$ & $9.6 \pm 0.16$ \\
$\mathrm{Fe}$ & $121 \pm 4$ & $133 \pm 4$ \\
$\mathrm{Mn}$ & $6.8 \pm 1.4$ & $7.3 \pm 0.2$ \\
$\mathrm{Mo} *$ & 0.36 & \\
$\mathrm{Ni}^{*}$ & $0.97 \pm 0.02$ & $(1.0)$ \\
$\mathrm{Pb} *$ & $1.89 \pm 0.01$ & $1.91 \pm 0.04$ \\
$\mathrm{Tl}$ & $<0.001$ & \\
$\mathrm{~V}^{*}$ & $0.55 \pm 0.03$ & \\
$\mathrm{Zn}$ & $75 \pm 3$ & $76 \pm 2$ \\
\hline
\end{tabular}

\subsection{Reagents and calibration}

The reagents used, nitric acid $(65 \% \mathrm{w} / \mathrm{v})$ and hydrogen peroxide $(30 \% \mathrm{w} / \mathrm{v})$, were suprapure (Suprapur, Merck, Darmstadt, FRG). High-purity water (electrical resistivity $>18 \mathrm{M} \Omega \mathrm{cm}$ ) was produced with a Milli-Q system (Millipore, MA, USA). Calibration for ICP-OES was obtained with external standards. Standard solutions were prepared by diluting a $1000 \mathrm{mg} \mathrm{L}^{-1}$ multielement solution (ICP Multielement Standard IV, Merck, Darmstadt, FRG) with the same acid amount used for sample dissolution. Glassware was cleaned by soaking with the contact overnight in a $10 \%(\mathrm{w} / \mathrm{v})$ nitric acid solution and then rinsed with deionized water.

Calibration for ICP MS was also obtained with external standards. Standard solutions were prepared diluting by weight a $1000 \mathrm{mg} \mathrm{L}^{-1}$ multielement solution (Romil Ltd, Cambridge, UK). Ultra pure nitric acid, also from Romil (Romil UpA), was twice redistilled before use. The containment materials were in FEP (Fluorinated Ethylene Propylene) from NALGENE (Thermo Fisher Scientific Inc., Waltham, MA 02454, USA) and used after an internal, well-established 2 week cleaning procedure. All the chemical operations were performed in a Clean Room ( $<100$ Class $)$.

\subsection{Chemical analyses and instrumentation}

The analytical determination of $\mathrm{Ca}, \mathrm{Cu}, \mathrm{Fe}, \mathrm{Mn}$ and $\mathrm{Zn}$ was carried out using the ICPOES Jobin Yvon (Jobin Yvon Emission Horiba Group, Long Jumeau, Cedex, France) JY 24 model. Table 3 gives some basic information about the operating conditions of the ICPOES spectrometer. The other elements $(\mathrm{Be}, \mathrm{V}, \mathrm{Cr}, \mathrm{Co}$, $\mathrm{Ni}, \mathrm{As}, \mathrm{Mo}, \mathrm{Cd}, \mathrm{Pb}$ ) present in tissue samples at trace level concentration were measured by ICP-MS using an Agilent 7500ce (Agilent Technologies, Palo Alto, Ca 94306, USA) equipped with the Collision /Reaction
Cell. The instrumental operating conditions are summarized in table 4. During ICP-MS measurements, isobaric interferences can arise from both the argon used to sustain the plasma and the reagents involved in the sample preparation. In particular, there are well-known interferences in tissue samples that can overlap the masses of $\mathrm{Cr}, \mathrm{V}$ and As at trace levels. As reported above, the sample preparation method must obviate this problem by avoiding the introduction of chloride-based interferences. In addition, the combined use of the collision cell and the measurement of two separate isotopes for elements like $\mathrm{Cr}$ and $\mathrm{Cu}$ results in real agreement with the expected values certified in the Reference Standard Material used (Tab. 2).

Tab. 3. Instrument operating parameters of ICP-OES JY24.

\begin{tabular}{|c|c|}
\hline \multicolumn{2}{|l|}{ Parameter } \\
\hline Incident power (W) & 950 \\
\hline Reflected power (W) & $<5$ \\
\hline \multicolumn{2}{|l|}{ Ar gas flow rate $\left(\mathrm{L} \mathrm{min}^{-1}\right)$} \\
\hline Outer gas & 13 \\
\hline Auxiliary gas & $<1$ \\
\hline Aerosol gas & 0.9 \\
\hline \multicolumn{2}{|l|}{ Nebulizer } \\
\hline Model & Cross-flow - Scott chamber \\
\hline Sample flow rate $\left(\mathrm{mL} \mathrm{min}^{-1}\right)$ & 1.5 \\
\hline Pump of sample injection & Gilson miniplus 2 \\
\hline
\end{tabular}

Tab. 4. ICP-MS Agilent 7500ce Operating Conditions.

\begin{tabular}{|c|c|}
\hline \multicolumn{2}{|l|}{ Parameter } \\
\hline Plasma RF Power (W) & 1500 \\
\hline Carrier Gas Flow $\left(\mathrm{L} \min ^{-1}\right)$ & 1.1 \\
\hline Sample depth (mm) & 9.5 from load coil \\
\hline Spray Chamber Temperature $\left({ }^{\circ} \mathrm{C}\right)$ & $2 \div 3$ \\
\hline Sample flow rate $\left(\mu \mathrm{L} \min ^{-1}\right)$ & 250 \\
\hline Nebulizer & Agilent microflow PFA \\
\hline Interface & Níckel simple and skimmer cones \\
\hline
\end{tabular}

\subsection{Calculations}

To evaluate the similarity between the seasonal trends of concentrations of the different metals in the tissues of mussels from each lake, considered separately, the significance level for the 91 combinations of the 14 metals was calculated using the Pearson correlation matrix. The significance levels were $p<0.01$ (highly significant) and $p<0.05$ (significant). The same method was used to evaluate the seasonal variations of each single metal in the tissues of molluscs from the two lakes, considered together for comparative purposes.

The concentration factor (C.F.) was calculated as the ratio between the concentration of the element in the mussel tissues (related to wet weight) and its concentration in the filtered water. For each element the mean annual concentration in the mussel tissues was divided by the mean concentration in the water. The wet weight/dry weight ratio (9.66 for Lake Maggiore and 
Tab. 5. Mean concentration standard deviation and coefficient of variation (\% CV) of elements in tissues and shell of mussels from Lake Maggiore and Lake Candia. The mean values are expressed in $\mu \mathrm{g} \mathrm{g}^{-1} \mathrm{~d} . \mathrm{w}$. except for calcium ( $\mathrm{mg} \mathrm{g}^{-1}$ d.w.) and beryllium (ng g ${ }^{-1}$ d.w.).

\begin{tabular}{|c|c|c|c|c|c|c|c|c|c|c|c|c|}
\hline & \multicolumn{6}{|c|}{ Lake Maggiore } & \multicolumn{6}{|c|}{ Lake Candia } \\
\hline & \multicolumn{3}{|c|}{ tissue } & \multicolumn{3}{|c|}{ shell } & \multicolumn{3}{|c|}{ tissue } & \multicolumn{3}{|c|}{ shell } \\
\hline & mean & SD & $\% \mathrm{CV}$ & mean & $\mathrm{SD}$ & $\% \mathrm{CV}$ & mean & $\mathrm{SD}$ & $\% \mathrm{CV}$ & mean & $\mathrm{SD}$ & $\% \mathrm{CV}$ \\
\hline $\mathrm{Ca}$ & 60.9 & 11.0 & 18 & 365 & 18 & 4.9 & 16.1 & 2.5 & 16 & 365 & 21 & 5.7 \\
\hline Mn & 6470 & 1200 & 19 & 189 & 19 & 10 & 3690 & 620 & 17 & 737 & 86 & 12 \\
\hline $\mathrm{Fe}$ & 2390 & 570 & 24 & 108 & 50 & 46 & 1840 & 290 & 16 & 245 & 92 & 37 \\
\hline $\mathrm{Zn}$ & 840 & 194 & 23 & 3.61 & 0.88 & 24 & 120 & 12 & 10 & 1.82 & 0.44 & 24 \\
\hline $\mathrm{Cu}$ & 28.0 & 7.06 & 25 & 5.51 & 0.99 & 18 & 12.7 & 6.35 & 50 & 3.21 & 1.25 & 39 \\
\hline $\mathrm{Pb}$ & 12.0 & 6.41 & 54 & 0.49 & 0.16 & 34 & 2.64 & 1.48 & 56 & 0.26 & 0.05 & 18 \\
\hline As & 9.05 & 1.48 & 16 & 0.52 & 0.15 & 28 & 2.68 & 0.34 & 13 & 0.43 & 0.17 & 40 \\
\hline $\mathrm{Ni}$ & 6.95 & 3.34 & 48 & 6.48 & 2.04 & 31 & 4.22 & 1.70 & 40 & 5.50 & 1.15 & 21 \\
\hline $\mathrm{Cr}$ & 3.97 & 1.00 & 25 & 0.64 & 0.33 & 52 & 1.48 & 0.41 & 28 & 0.46 & 0.19 & 41 \\
\hline $\mathrm{Cd}$ & 3.56 & 1.05 & 30 & 0.05 & 0.02 & 33 & 0.75 & 0.13 & 18 & 0.04 & 0.02 & 52 \\
\hline $\mathrm{Co}$ & 0.89 & 0.09 & 10 & 0.81 & 0.04 & 5.4 & 0.59 & 0.09 & 15 & 0.61 & 0.05 & 8.7 \\
\hline V & 0.65 & 0.28 & 42 & 0.12 & 0.04 & 33 & 0.21 & 0.08 & 37 & 0.08 & 0.04 & 55 \\
\hline Mo & 0.53 & 0.08 & 16 & 0.07 & 0.04 & 57 & 0.27 & 0.05 & 18 & 0.09 & 0.07 & 78 \\
\hline $\mathrm{Be}$ & 21.5 & 11.4 & 53 & 4.50 & 3.28 & 73 & 7.92 & 5.75 & 73 & 1.55 & 0.86 & 55 \\
\hline
\end{tabular}

8.65 for Lake Candia mussels, Ravera et al. 2007) was applied to calculate the element concentrations in the tissue wet weight from the concentrations measured in the dried material.

The flesh condition index (F.C., tissue dry weight/shell dry weight ratio, Lobel and Wright 1982) and the condition index (C.I., ratio between the tissue dry weight and the product of shell length, width and height, Lobel et al. 1991) were calculated to estimate the level of dilution of the elements produced by the mussel soft tissues. The value of both indices generally increases as the metal concentration in the tissues decreases. We devised another index, the Influence index (I.i.), as an attempt to estimate the potential influence of the metal contents in the mussel population biomass on its habitat. This index is calculated as the ratio between the metal content in the mussel (soft tissue and shell) biomass per sediment surface unit and the metal concentration in the lake water. The value of the index is expressed as the volume of water $\left(\mathrm{m}^{-3}\right)$ with the same metal concentration as in the lake water.

$$
\text { I.i. }=A B / C \times 10^{3}
$$

where: $A=$ metal concentration in the biomass $\left(\mu \mathrm{g} \mathrm{g}^{-1}\right)$; $B=$ dry weight of the biomass $\left(\mathrm{g} \mathrm{m}^{-2}\right) ; C=$ metal concentration in the lake water $\left(\left(\mu \mathrm{g} \mathrm{L}^{-1}\right)\right.$.

\section{RESULTS}

\subsection{Element concentrations in shell, soft tissues and water}

The mean concentration, standard deviation and coefficient of variation $(\% \mathrm{CV})$ of elements in the soft tissues and shell of mussels from Lake Maggiore and Lake Candia are reported in table 5. In both lakes, most element concentrations showed wide variations over time in both mussel shell and tissues, as can be seen from the relatively high coefficients of variation. Altogether, most of the elements examined revealed higher concentrations in both shell and tissues of the Lake Maggiore mussels.

The mean concentrations of elements in filtered water are given in table 6. Element concentrations were generally higher in Lake Maggiore than in Lake Candia, except for $\mathrm{Mn}, \mathrm{Fe}$ and $\mathrm{Ni}$, which were higher in Lake Candia, and for $\mathrm{Co}$ and $\mathrm{Cd}$ concentrations, which were similar in the two lakes.

Tab. 6. Element concentrations (mean $\pm \mathrm{SD}$ ) in filtered $(0.45 \mu \mathrm{m})$ lake water.

\begin{tabular}{|c|c|c|}
\hline Element & Lake Maggiore & Lake Candia \\
\hline $\mathrm{mg} \mathrm{Ca} \mathrm{L}^{-1}$ & $26.4 \pm 5.30$ & $15.1 \pm 2.8$ \\
\hline$\mu \mathrm{g} \mathrm{Zn} \mathrm{L} \mathrm{L}^{-1}$ & $77.2 \pm 52.6$ & $40.1 \pm 14.2$ \\
\hline$\mu \mathrm{g} \mathrm{Fe} \mathrm{L}{ }^{-1}$ & $37.2 \pm 48.7$ & $93.3 \pm 93.2$ \\
\hline$\mu \mathrm{g} \mathrm{Mn} \mathrm{L}^{-1}$ & $20.0 \pm 39.4$ & $55.1 \pm 52.8$ \\
\hline$\mu \mathrm{g} \mathrm{Cu} \mathrm{L}^{-1}$ & $2.10 \pm 0.32$ & $2.00 \pm 0.00$ \\
\hline$\mu \mathrm{g} \mathrm{Ni} \mathrm{L}-1$ & $1.60 \pm 0.55$ & $1.85 \pm 0.44$ \\
\hline$\mu \mathrm{g}$ As L $\mathrm{L}^{-1}$ & $1.36 \pm 0.33$ & $0.51 \pm 0.11$ \\
\hline$\mu \mathrm{g} \mathrm{Mo} \mathrm{L}{ }^{-1}$ & $0.71 \pm 0.16$ & $0.19 \pm 0.09$ \\
\hline$\mu \mathrm{g} \mathrm{Pb} \mathrm{L} \mathrm{L}^{-1}$ & $0.48 \pm 0.22$ & $0.29 \pm 0.09$ \\
\hline$\mu \mathrm{g} \mathrm{Cr} \mathrm{L}^{-1}$ & $0.33 \pm 0.60$ & $0.12 \pm 0.03$ \\
\hline$\mu \mathrm{g} \mathrm{V} \mathrm{L}^{-1}$ & $0.28 \pm 0.12$ & $0.12 \pm 0.07$ \\
\hline$\mu \mathrm{g} \mathrm{Co} \mathrm{L}{ }^{-1}$ & $0.09 \pm 0.05$ & $0.09 \pm 0.01$ \\
\hline$\mu \mathrm{g} \mathrm{Cd} \mathrm{L}{ }^{-1}$ & $0.02 \pm 0.01$ & $0.02 \pm 0.01$ \\
\hline ng Be L ${ }^{-1}$ & $0.98 \pm 0.83$ & $0.19 \pm 0.23$ \\
\hline
\end{tabular}

The decreasing sequences of the mean element concentrations in the soft tissues, shell and filtered water from Lake Maggiore and Lake Candia were quite similar, the greatest differences being in the elements with the lowest concentrations, such as $\mathrm{Co}$ and $\mathrm{Pb}$ in shells and tissues from both lakes (Tab. 7).

The F.C. and the C.I. were both lower in Lake Maggiore mussels than in the Lake Candia mussels (Tab. 8). The C.F. for each element from both lakes and their ratios are listed in table 9. 
Tab. 7. The decreasing sequences of the mean element concentrations in the soft tissues, shell and filtered water from Lake Maggiore and Lake Candia.

\begin{tabular}{|c|c|c|}
\hline L. Maggiore & $\begin{array}{l}\text { tissues } \\
\text { shell } \\
\text { water }\end{array}$ & $\begin{array}{l}\mathrm{Ca}>\mathrm{Mn}>\mathrm{Fe}>\mathrm{Zn}>\mathrm{Cu}>\mathrm{Pb}>\mathrm{As}>\mathrm{Ni}>\mathrm{Cr}>\mathrm{Cd}>\mathrm{Co}>\mathrm{V}>\mathrm{Mo}>\mathrm{Be} \\
\mathrm{Ca}>\mathrm{Mn}>\mathrm{Fe}>\mathrm{Ni}>\mathrm{Cu}>\mathrm{Zn}>\mathrm{Co}>\mathrm{Cr}>\mathrm{As}>\mathrm{Pb}>\mathrm{V}>\mathrm{Mo}>\mathrm{Cd}>\mathrm{Be} \\
\mathrm{Ca}>\mathrm{Zn}>\mathrm{Fe}>\mathrm{Mn}>\mathrm{Cu}>\mathrm{Ni}>\mathrm{As}>\mathrm{Mo}>\mathrm{Pb}>\mathrm{Cr}>\mathrm{V}>\mathrm{Co}>\mathrm{Cd}>\mathrm{Be}\end{array}$ \\
\hline L. Candia & $\begin{array}{l}\text { tissues } \\
\text { shell } \\
\text { water }\end{array}$ & $\begin{array}{l}\mathrm{Ca}>\mathrm{Mn}>\mathrm{Fe}>\mathrm{Zn}>\mathrm{Cu}>\mathrm{Ni}>\mathrm{As}>\mathrm{Pb}>\mathrm{Cr}>\mathrm{Cd}>\mathrm{Co}>\mathrm{Mo}>\mathrm{V}>\mathrm{Be} \\
\mathrm{Ca}>\mathrm{Mn}>\mathrm{Fe}>\mathrm{Ni}>\mathrm{Cu}>\mathrm{Zn}>\mathrm{Co}>\mathrm{Cr}>\mathrm{As}>\mathrm{Pb}>\mathrm{Mo}>\mathrm{V}>\mathrm{Cd}>\mathrm{Be} \\
\mathrm{Ca}>\mathrm{Fe}>\mathrm{Mn}>\mathrm{Zn}>\mathrm{Cu}>\mathrm{Ni}>\mathrm{As}>\mathrm{Pb}>\mathrm{Mo}>\mathrm{V}>\mathrm{Cr}>\mathrm{Co}>\mathrm{Cd}>\mathrm{Be}\end{array}$ \\
\hline
\end{tabular}

Tab. 8. Mean value of the tissues and shell dry weight and mean volume of mussel calculated on length, width and height of shell. These variables refer to mussels ranging from $64 \mathrm{~mm}$ to $71 \mathrm{~mm}$ length, the size interval of the specimens analysed for trace elements. F.C. $=$ flesh condition index, C.I. $=$ concentration index.

\begin{tabular}{lcc}
\hline & Lake Maggiore & Lake Candia \\
\hline tissues $(\mathrm{g})$ & 1.32 & 1.74 \\
shell $(\mathrm{g})$ & 13.87 & 11.20 \\
volume $(\mathrm{ml})$ & 46.77 & 46.79 \\
F.C. & 0.095 & 0.155 \\
C.I. & 0.028 & 0.037 \\
\hline
\end{tabular}

Tab. 9. Concentration factors calculated for the mussel tissues from Lake Maggiore and Lake Candia and the ratios between the concentration factors.

\begin{tabular}{cccc}
\hline \multirow{2}{*}{ Element } & \multicolumn{2}{c}{ Concentration factor } & \multirow{2}{*}{$\mathrm{CF}_{\mathrm{LM}} / \mathrm{CF}_{\mathrm{LC}}$} \\
\cline { 2 - 3 } & Lake Maggiore & Lake Candia & \\
\hline $\mathrm{Mn}$ & 33473 & 7732 & 4.33 \\
$\mathrm{Fe}$ & 6661 & 2282 & 2.92 \\
$\mathrm{Cd}$ & 15796 & 5523 & 2.86 \\
$\mathrm{~Pb}$ & 2564 & 1049 & 2.44 \\
$\mathrm{Be}$ & 2275 & 4821 & 0.47 \\
$\mathrm{Ca}$ & 239 & 123 & 1.94 \\
$\mathrm{Cu}$ & 1382 & 732 & 1.89 \\
$\mathrm{Ni}$ & 450 & 264 & 1.70 \\
$\mathrm{Co}$ & 1023 & 803 & 1.27 \\
$\mathrm{~V}$ & 241 & 202 & 1.19 \\
$\mathrm{As}$ & 689 & 601 & 1.15 \\
$\mathrm{Cr}$ & 1229 & 1407 & 0.87 \\
$\mathrm{Mo}$ & 77 & 168 & 0.46 \\
$\mathrm{Zn}$ & 1126 & 346 & 3.26 \\
\hline
\end{tabular}

\subsection{Element contents in the biomass of mussel tissues and shell}

The results from the biomass of mussel populations from the two lakes (Ravera et al. 2007) were used to calculate the mean element contents in mussel soft tissues and shell per $\mathrm{m}^{-2}$ (schematized in Fig 1).

The "Influence index" (I.i.) was applied to estimate the potential influence on the environment of the metal contents in the mussels from the two lakes. The values are reported in table 10 . In both lakes, 8 elements $(\mathrm{Ca}$, $\mathrm{Cu}, \mathrm{Ni}, \mathrm{Cr}, \mathrm{Co}, \mathrm{V}, \mathrm{Mo}, \mathrm{Be}$ ) have index values higher for the shell than for the tissues; conversely, 4 elements (Fe, $\mathrm{Zn}, \mathrm{Pb}, \mathrm{Cd}$ ) have higher values for the tissues than for the shell. This is due to the metal concentrations being so high in the tissues that they exceed those of the large biomass of the shell and its metal contents. The index values calculated for the soft tissues and shell of the Lake Maggiore mussels are higher than those of Lake Candia mussels. In Lake Maggiore the index values of $\mathrm{Mn}$ and As for the tissues are higher than those for the shell, while in Lake Candia the opposite is the case.

\subsection{Seasonal variation patterns of element concentrations in the soft tissues and shell}

The monthly variations of element concentrations in the shell and soft tissues are schematized in Figs 2a, 2b and $2 \mathrm{c}$. All the element concentrations in the tissues of Lake Maggiore mussels were higher than those in Lake Candia mussels and generally showed a wider range of variation. 

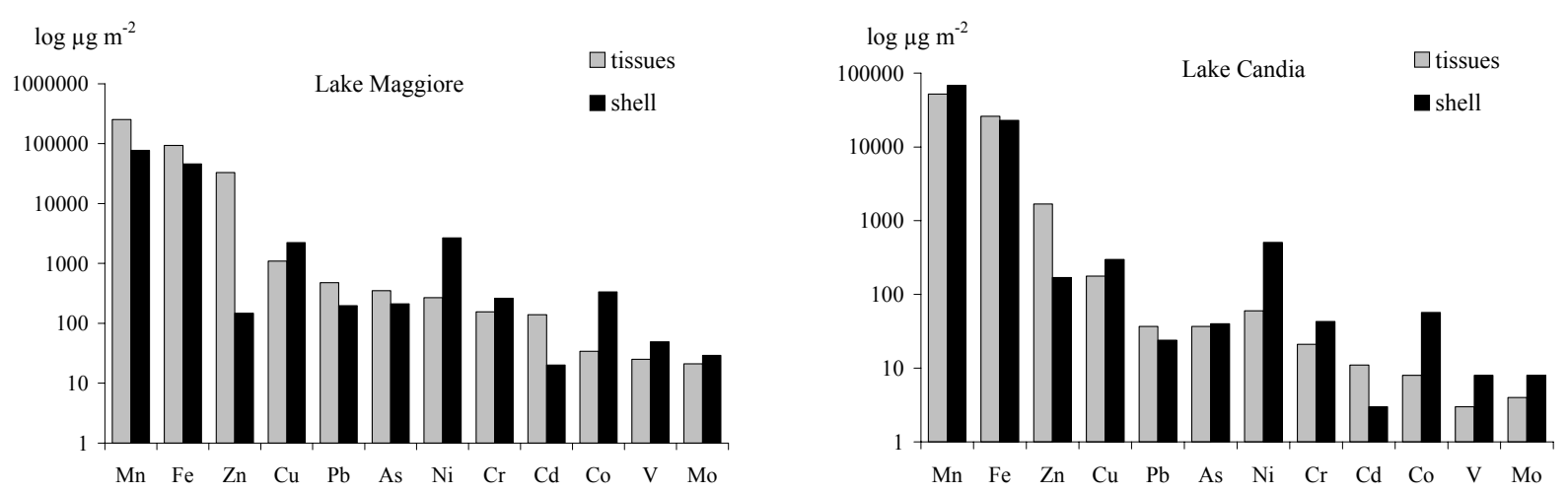

Fig. 1. Mean element contents in the shell and soft tissue biomass (dry weight) of mussels from Lake Maggiore and Lake Candia.

Tab. 10. Values of the I.i. (influence index) expressed in $\mathrm{m}^{3}$ of water corresponding to the ratio between the metal content in the tissues and shell biomass and the mean concentration of the same metal in lake water.

\begin{tabular}{cccccc}
\hline \multirow{2}{*}{ Element } & \multicolumn{2}{c}{ Lake Maggiore } & & \multicolumn{2}{c}{ Lake Candia } \\
\cline { 2 - 3 } \cline { 5 - 6 } & tissues & shell & & tissues & shell \\
\hline $\mathrm{Ca}$ & 0.09 & 5.64 & & 0.01 & 2.22 \\
$\mathrm{Mn}$ & 12.51 & 3.86 & & 0.94 & 1.23 \\
$\mathrm{Fe}$ & 2.48 & 1.18 & & 0.28 & 0.24 \\
$\mathrm{Zn}$ & 0.42 & 0.02 & & 0.04 & 0.004 \\
$\mathrm{Cu}$ & 0.52 & 1.07 & & 0.09 & 0.15 \\
$\mathrm{~Pb}$ & 0.97 & 0.42 & & 0.13 & 0.08 \\
$\mathrm{As}$ & 0.26 & 0.16 & & 0.07 & 0.08 \\
$\mathrm{Ni}$ & 0.17 & 1.65 & & 0.03 & 0.27 \\
$\mathrm{Cr}$ & 0.46 & 0.79 & & 0.18 & 0.35 \\
$\mathrm{Cd}$ & 6.90 & 1.00 & & 0.50 & 0.20 \\
$\mathrm{Co}$ & 0.38 & 3.67 & & 0.09 & 0.62 \\
$\mathrm{~V}$ & 0.09 & 1.75 & & 0.02 & 0.06 \\
$\mathrm{Mo}$ & 0.03 & 0.04 & & 0.02 & 0.04 \\
$\mathrm{Be}$ & 0.85 & 1.87 & 0.58 & 0.75 \\
\hline
\end{tabular}

The similarity levels of the seasonal patterns of the different elements in the mussel tissues from each lake are reported in table 11 . A highly significant correlation between the tissue concentrations of 14 pairs of elements, and a significant correlation between that of 17 pairs, were observed in Lake Maggiore; in Lake Candia 11 element pairs were correlated at a highly significant $p$-level, 8 pairs at a significant $p$-level. The element pairs with a high degree of correlation showed a very similar pattern of seasonal variation, characterized by generally low concentrations in summer 2003 followed by high concentrations in autumn-winter, a decrease in early spring and an increase in summer 2004. A less evident, but similar, pattern of variation characterized the element pairs correlated with a lower degree of significance. All the significantly correlated pairs $(p<0.01$ and $p<0.04)$ show a positive relationship, the sole exception being the highly significant negative correlation between Mo and $\mathrm{Ni}$ concentrations in the tissues of Lake Candia mussels, which showed a mirrored pattern of seasonal variation.

The between-lakes similarity level of each element in the mussel tissues was also tested, but only two ele- ments $(\mathrm{Ni}$ and $\mathrm{Pb})$ showed a close similarity in the two lakes.

\section{DISCUSSION AND CONCLUSIONS}

The aim of this study was to compare some important biological and ecotoxicological characteristics of two U. pictorum mancus populations living in two lakes of different trophic state. As this study was carried out simultaneously on the same monthly samplings of populations of Unio pictorum mancus from two lakes (the mesooligotrophic Lake Maggiore and the eutrophic Lake Candia), it was possible to compare the biological and chemical characteristics of both populations.

Generally, element concentrations were higher in the tissues than in the shell of both populations. The ratio between element concentrations in the tissues and those in the shell of Lake Maggiore mussels was always higher than those in Lake Candia. This is the result of high metal concentrations in the tissues calculated for Lake Maggiore mussels rather than low concentrations in the shell. 

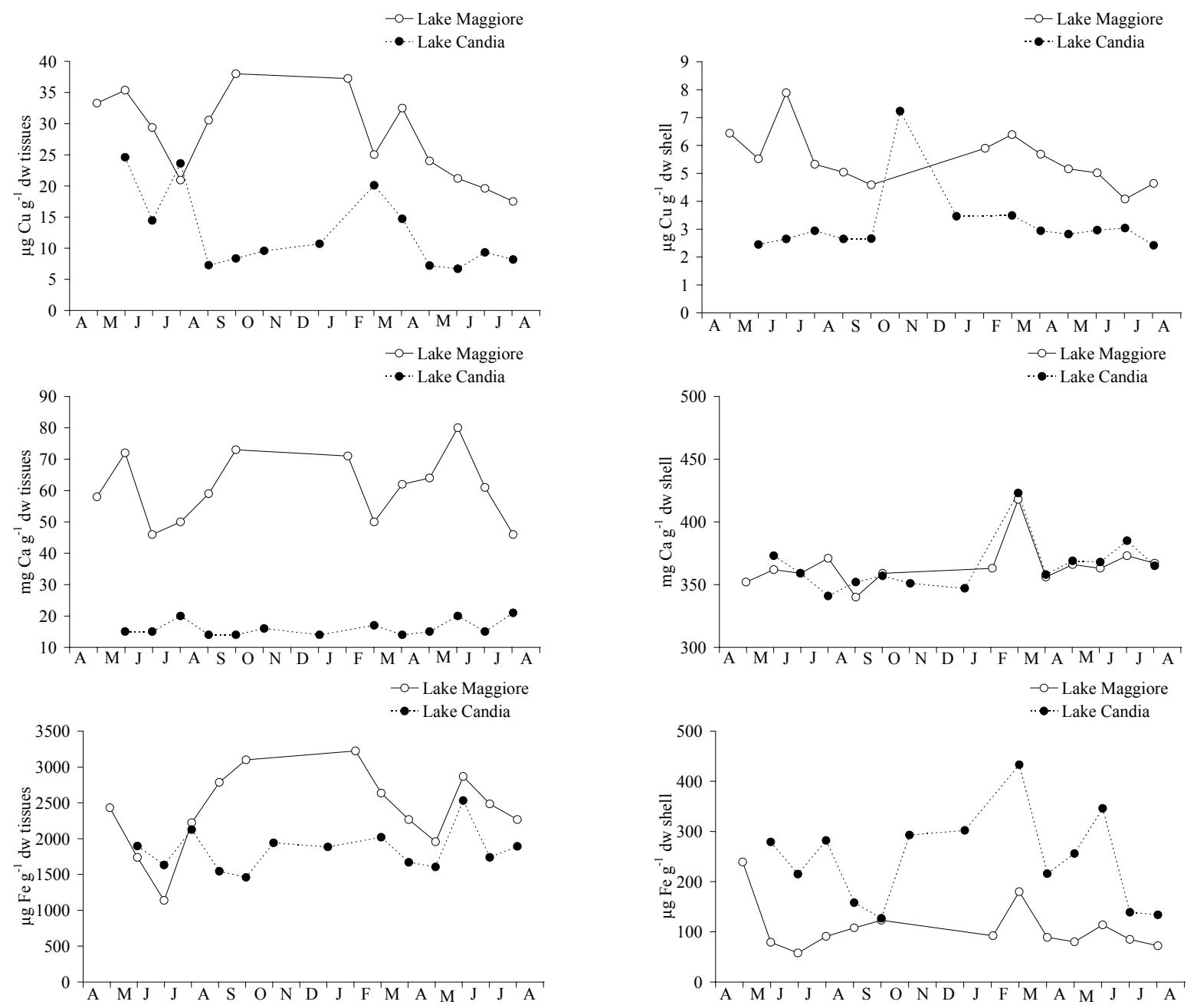

- Lake Maggio
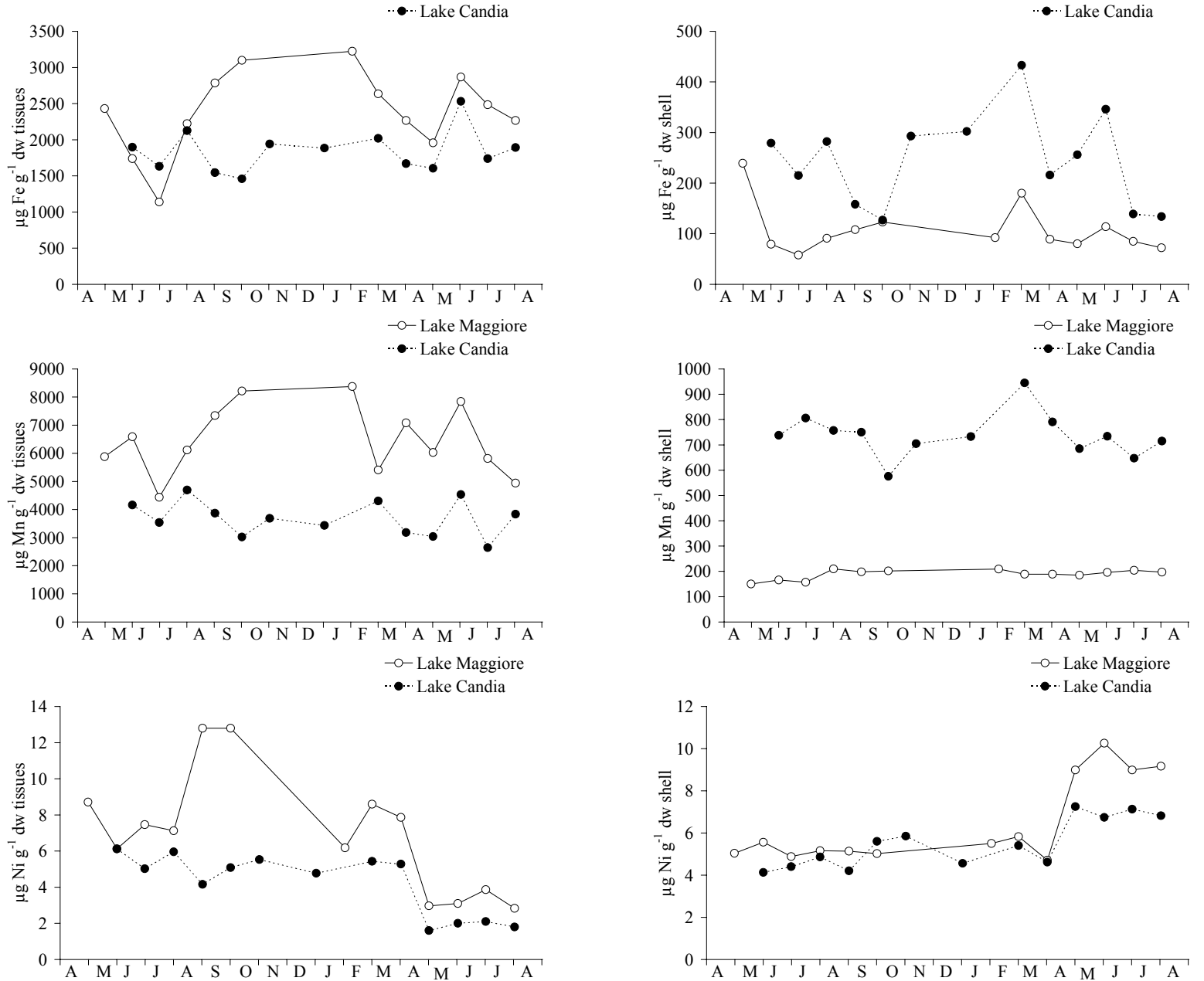

Fig. 2a. Seasonal variations of element concentrations in shell and soft tissues of Unio pictorum mancus from Lake Maggiore and Lake Candia. 

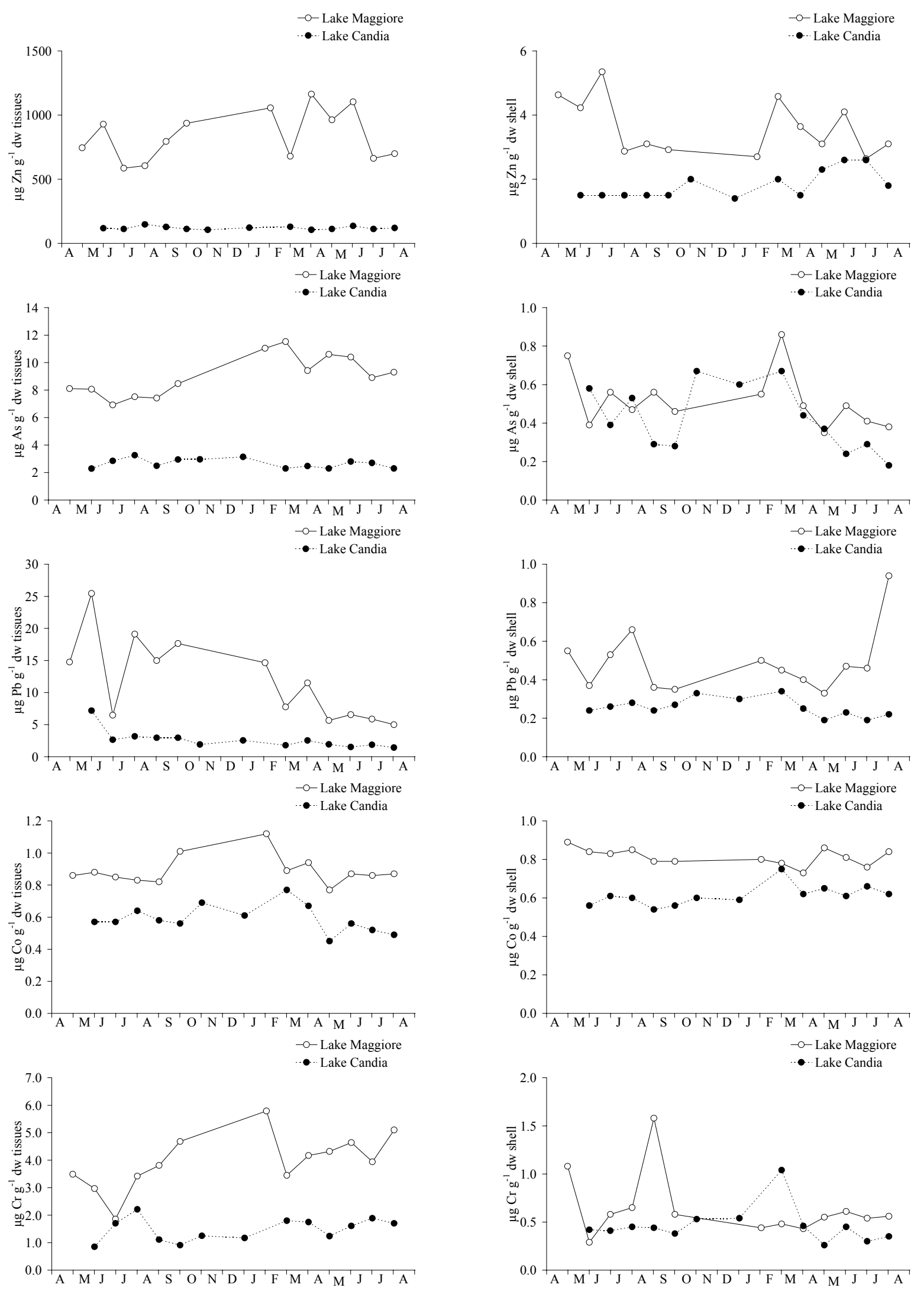

Fig. 2b. Seasonal variations of element concentrations in shell and soft tissues of Unio pictorum mancus from Lake Maggiore and Lake Candia. 

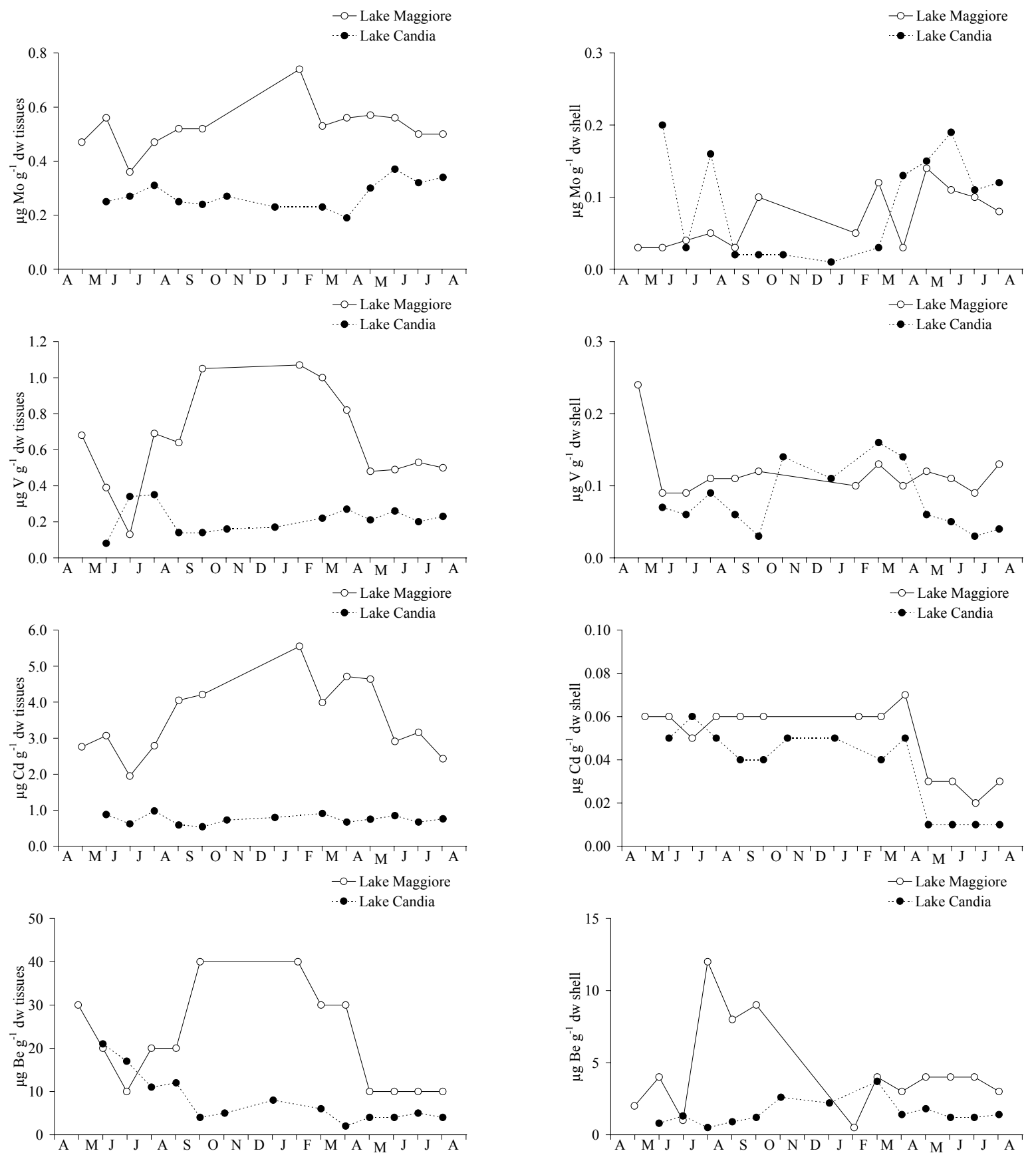

Fig. 2c. Seasonal variations of element concentrations in shell and soft tissues of Unio pictorum mancus from Lake Maggiore and Lake Candia. 
Tab. 11. Correlation matrix calculated for 91 combinations of elements in mussel tissues from Lake Maggiore (above diagonal) and lake Candia (below diagonal). $* *=$ highly significant $(p<0.01), *=$ significant $(p<0.04)$.

\begin{tabular}{|c|c|c|c|c|c|c|c|c|c|c|c|c|c|c|}
\hline & $\mathrm{Zn}$ & $\mathrm{Cu}$ & $\mathrm{Ca}$ & $\mathrm{Fe}$ & Mn & $\mathrm{Ni}$ & As & $\mathrm{Pb}$ & $\mathrm{Co}$ & $\mathrm{Cr}$ & Mo & V & $\mathrm{Cd}$ & $\mathrm{Be}$ \\
\hline $\mathrm{Zn}$ & & n.s. & $0.801 * *$ & n.s. & $0.760 * *$ & n.s. & n.s. & n.s. & n.s. & n.s. & $0.714 * *$ & n.s. & $0.643 *$ & n.s. \\
\hline $\mathrm{Cu}$ & n.s. & & n.s. & n.s. & n.s. & $0.635^{*}$ & n.s. & $0.630^{*}$ & $0.602 *$ & n.s. & n.s. & n.s. & n.s. & $0.759 * *$ \\
\hline $\mathrm{Ca}$ & $0.621 *$ & n.s. & & n.s. & $0.833 * *$ & n.s. & n.s. & n.s. & n.s. & n.s. & $0.617^{*}$ & n.s. & n.s. & n.s. \\
\hline $\mathrm{Fe}$ & $0.628 *$ & n.s. & $0.738 * *$ & & $0.746 * *$ & n.s. & n.s. & n.s. & $0.570 *$ & $0.761 * *$ & $0.619 *$ & n.s. & n.s. & n.s. \\
\hline Mn & $0.801 * *$ & n.s. & $0.661 *$ & $0.739 * *$ & & n.s. & n.s. & n.s. & $0.607 *$ & $0.602 *$ & $0.703 * *$ & n.s. & $0.652 *$ & n.s. \\
\hline $\mathrm{Ni}$ & n.s. & $0.704 * *$ & n.s. & n.s. & n.s. & & n.s. & n.s. & n.s. & n.s. & n.s. & n.s. & n.s. & $0.633^{*}$ \\
\hline As & n.s. & n.s. & n.s. & n.s. & n.s. & n.s. & & n.s. & n.s. & $0.606^{*}$ & $0.684 * *$ & n.s. & n.s. & n.s. \\
\hline $\mathrm{Pb}$ & n.s. & $0.634^{*}$ & n.s. & n.s. & n.s. & n.s. & n.s. & & n.s. & n.s. & n.s. & n.s. & n.s. & n.s. \\
\hline $\mathrm{Co}$ & n.s. & n.s. & n.s. & n.s. & n.s. & $0.726^{* *}$ & n.s. & n.s. & & n.s. & $0.626^{*}$ & $0.683 *$ & n.s. & $0.770 * *$ \\
\hline $\mathrm{Cr}$ & n.s. & n.s. & n.s. & n.s. & n.s. & n.s. & n.s. & n.s. & n.s. & & $0.761 * *$ & n.s. & $0.586^{*}$ & n.s. \\
\hline Mo & n.s. & n.s. & $0.736 * *$ & n.s. & n.s. & $-0.699 * *$ & n.s. & n.s. & n.s. & n.s. & & $0.576^{*}$ & $0.808 * *$ & n.s. \\
\hline $\mathrm{V}$ & n.s. & n.s. & n.s. & n.s. & n.s. & n.s. & n.s. & n.s. & n.s. & $0.844 * *$ & n.s. & & $0.712 * *$ & $0.870 * *$ \\
\hline $\mathrm{Cd}$ & $0.654 *$ & $0.621 *$ & $0.600 *$ & $0.771 * *$ & $0.729 * *$ & n.s. & n.s. & n.s. & n.s. & n.s. & n.s. & n.s. & & $0.609 *$ \\
\hline $\mathrm{Be}$ & n.s. & $0.583 *$ & n.s. & n.s. & n.s. & n.s. & n.s. & $0.782 * *$ & n.s. & n.s. & n.s. & n.s. & n.s. & \\
\hline
\end{tabular}

The capacity of taxa such as mussels for accumulating various pollutants (for example, trace elements) in their body tissues has been exploited to develop the socalled concentration factor (C.F.). The C.F.s calculated for mussel tissues from Lake Maggiore were higher than those of the corresponding elements from Lake Candia, with the exception of the C.F.s for Be, Mo and Cr, which were higher in Lake Candia. Consequently, except for these three elements, the ratios between the C.F.s of Lake Maggiore and those of the same elements of Lake Candia were higher than 1 for all the elements. While a ratio equal to 1 would suggest that tissue accumulation depends solely on water concentration, a departure from unity indicates that other factors, such as the abundance of available element forms in water and/or food, can affect metal intake and accumulation.

A drawback of the C.F. index is that the concentration in the tissues, which results from the accumulation of elements over a relatively long time, must be compared with the concentration in the water, which reflects the environmental situation at the moment of sampling. To minimize this difficulty we compared the mean element concentrations in the tissues with the mean values in the water. Although the water element concentrations were similar in both lakes, the C.F. of the Lake Maggiore population was distinctly higher for most of the elements. Similar observations have been made by other authors (Johnson et al. 1993; Ravera et al. 2003), and Metcalfe-Smith et al. (1992) observed that mussels from uncontaminated environments were frequently more highly contaminated than those from clean waters.

One of the main reasons for the lack of correlation between element concentration in the water and in the tissues of the organism is the tendency to consider the total element concentration in the water instead of the element forms available to the mussel (e.g., Ravera 2004; Maruo \& Orians 2006). Generally, the ionic form of an element is the most readily available, though there are exceptions (e.g., $\mathrm{Hg}, \mathrm{Pb}, \mathrm{Sn}$ ). The particulate form may also be important for filter feeding animals like mussels. The relative proportion of the various element forms varies in relation to the element as well as to environmental conditions. For example, Muntau (1981) found in water samples from an area of Lake Maggiore close to our sampling station that the percentages of elements in particulate form were: $\mathrm{Cu} 15 \%$; $\mathrm{Zn} 18 \%$ and $\mathrm{Cd} 39 \%$, and in ionic or weakly chelated form: $\mathrm{Cu} 62 \%$, $\mathrm{Zn} 25 \%$ and $\mathrm{Cd} 56 \%$. In spite of continually improving methods for metal species identification and quantification, field studies on aquatic invertebrates in relation to element forms are very scarce (e.g., Lee et al. 2006). In spite of drawbacks, however, the use of accumulator organisms in biomonitoring yields reliable results in identifying new pollutants (e.g., artificial radioisotopes) or in estimating temporal and spatial differences in trace element concentrations.

The values of the flesh condition index (F.C.) and those of the condition index (C.I.) were both lower in Lake Maggiore than in Lake Candia mussels, in which the concentration of all the metals in the tissues was lower than in Lake Maggiore (Tab. 8). This is in agreement with the general rule of these indices, which is that their values decrease as the metal concentrations in the tissues increase.

Information on trace element concentrations in mussel tissues is very abundant, less so for the shell and very poor for trace element contents in the shell and tissue biomass. The higher element contents in the tissue and shell biomass of mussels from Lake Maggiore than in the mussels from Lake Candia are due mainly to greater population density, and to a lesser extent to higher element concentrations in the tissues. Mean individual weight, which is greater in Lake Candia mussels, is of negligible importance for mussel biomass. Indeed, the population density of mussels in Lake Maggiore (46.86 individuals $\mathrm{m}^{-2}$ ) exceeded that in Lake Candia (6.93 individuals $\mathrm{m}^{-2}$ ) by a factor of about 7 . In Lake Maggiore, therefore, mussels can be expected to exert a greater influence on the biogeochemical cycles of elements than in Lake Candia.

Monitoring the seasonal variations of element concentrations in mussel tissues, besides providing infor- 
mation on element metabolism over the year, is useful for calculating the actual mean concentration of the elements. Certainly, the wide seasonal variations in element concentrations show the inadequacy of calculating element concentration from samples collected in a single season. The differences between the patterns of variation over time of the same element in shell and tissues may be explained by the turnover time of the elements, which is markedly shorter in the soft tissues than in the shell. Consequently, element concentrations in the tissues may vary over the seasons in relation to the physiological needs of the mussel and the abundance of the elements in available forms in water and food. Conversely, the greatest part of the elements present in the shell is adsorbed from the water to the periostracum, while a relatively smaller amount (except for $\mathrm{Ca}$ ) is transferred from the mantle to the shell during the whole life-span of the mussel. It follows that, although no seasonal pattern of element concentrations in the shell can be expected, a knowledge of these concentrations over time is essential for estimating the element content in the shell biomass related to the surface unit of the sediments. We found evidence of higher concentrations of several elements (e.g., Fe, Mn, Co, V, Be) in the soft tissues during the cold season. Other authors observed lower metal concentrations in the soft tissues of marine and freshwater bivalves in summer than in winter (e.g., Savari et al. 1991). Klaric et al. (2004) observed in winter and spring an As concentration increase in the soft tissues, due at least partly to the low nutrition status of mussels in these seasons.

A closer similarity of the seasonal pattern of the metal concentrations in the mussel tissues was observed in Lake Maggiore than in Lake Candia.

The positive correlation between some element pairs could be the result of their metabolic analogy and/or of seasonal variations of the available forms in the environment. Only one negative correlation was observed between the tissue concentrations of $\mathrm{Ni}$ and Mo in Lake Candia mussels. This may be due to a competitive inhibition for metabolic sites between these two elements with a similar ionic radius $\left(\mathrm{Ni}^{+2}=69 \AA\right.$ and $\mathrm{Mo}^{+4}=70$ $\AA$ ). Markich \& Jeffree (1994) demonstrated this mechanism clearly in laboratory experiments. This fact highlights the strong influence of environmental conditions on the seasonal variations of element concentrations in mussels.

In contrast with the similarity in the seasonal pattern of several metal pairs in the same lake, only two metals $(\mathrm{Ni}$ and $\mathrm{Pb}$ ) showed a similar seasonal pattern in the mussel tissues of both lakes, a fact which demonstrates that the behaviour of a given metal in the mussel can vary widely in different environments. Further research into this important problem is clearly required.

The metal content in a population represents the amount of metals immobilized in its biomass, which is equivalent to that transferred to the environment after the death of the population organisms. This influence on the environment, and particularly on biogeochemical cycles, was estimated by the Influence index (I.i.), which shows values higher for both the soft tissues and shell of Lake Maggiore mussels than for those of Lake Candia mussels.

Populations of $U$. pictorum mancus adapted to environments of different trophic state are characterized by marked biological and chemical differences. The population of the meso-oligotrophic Lake Maggiore showed a higher density and a larger total biomass per surface unit despite smaller individual size and a slower growth rate (Ravera et al. 2007), as well as higher trace element concentrations in the shell and tissues, compared to the population of the eutrophic Lake Candia. We can therefore conclude that, at least in our case, high trophy can reduce the impact of mussels on their habitat and particularly on biogeochemical cycles. Although the influence of eutrophication on mussels is evident (e.g. Patzner \& Müller 2001), it is rather difficult to identify the most important variables affecting the mussel and its capacity to accumulate metals. In the literature there is much more information on the influence of biological factors on metal accumulation in marine mussels (e.g., Mytilus) than in freshwater species.

Previous research (Ravera et al. 2003b) showed that trace element concentrations $(\mathrm{Cu}, \mathrm{Zn}, \mathrm{Fe}$ and $\mathrm{Mn})$ in $U$. pictorum mancus tissues from eutrophic lakes were lower than those from specimens inhabiting oligo- and meso-oligotrophic lakes, even though the concentrations in the eutrophic lake water were higher than those in the less productive lakes. The present study revealed higher element concentrations in both water and mussel tissues of the meso-oligotrophic Lake Maggiore than in the eutrophic Lake Candia. Two conclusions can be drawn from this comparison: 1) higher trace element concentrations in the water are not necessarily related to the high trophic state of the water body, and 2) high element concentrations in mussel tissues cannot be explained only by high element concentrations in the water; other causes must be involved, such as a high level of food contamination and/or a high percentage of available forms of the element in water.

\section{ACKNOWLEDGEMENTS}

We are grateful to Marie Paillet, Nicolas Diard, Matthieu Delaunay, Benoit Ginoux (Dpt. de Génie Biologique, Université de Toulon et du Var, France) for their help in the preparation of biological samples and chemical analyses, to Prof. Sandra Spence for the careful language revision of the manuscript and to the anonymous referees who contributed to improving the manuscript.

\section{REFERENCES}

Ambrosetti, W., L. Barbanti, R. Mosello \& A. Pugnetti. 1992. Limnological studies on the deep southern alpine lakes Maggiore, Lugano, Como, Iseo and Garda. In: Guilizzoni, 
P., G. Tartari and G. Giussani (Eds), Limnology in Italy. Mem. Ist. ital. Idrobiol., 50: 397-416.

Bryan, G.W. 1979. Bioaccumulation of marine pollutants. Philos. Trans. R. Soc. Lond. Ser. B, Biol. Sci., 286: 483505.

Dame, R., D. Bushek, D. Allen, A. Levitus, D. Edwards, E. Koeppler \& L. Gregory. 2002. Ecosystem response to bivalve density reduction: management implications. Aquat. Ecol., 36: 51-65.

Doherty, F.G., D.W. Evans \& E.F. Neuhauser. 1993. An assessment of total and leachable contaminants in zebra mussels (Dreissena polymorpha) from Lake Eire. Ecotoxicol. Environ. Saf., 25: 328-340.

Ferrington, J.W., E.D. Goldberg, R.W. Risebrough, J.H. Martin \& V.T. Bowen. 1983. U.S. Mussel Watch. 19761978. An overwiew of the trace-metals, DDT, PCB, hydrocarbon and artificial radionuclide data. Environ. Sci. Technol., 17: 490-496.

Gaglione, P. \& O. Ravera. 1964. Mn-54 concentration in fallout, water and Unio mussels of Lake Maggiore 1960-1963. Nature, 204: 1215-1216.

Giussani, G. \& G. Galanti. 1992. Experience in eutrophication recovery by biomanipulation. In: Guilizzoni, P., G. Tartari and G. Giussani (Eds), Limnology in Italy. Mem. Ist. ital. Idrobiol., 50: 397-416.

Johnson, R.K., T. Wiederholm \& D.M. Rosenberg. 1993. Freshwater biomonitoring using individual organisms, populations and species assemblages of benthic macroinvertebrates. In: D.M. Rosenberg \& W.H. Resh (Eds), Freshwater biomonitoring and benthic macroinvertebrates. Chapman and Hall, New York: 40-158.

Klarić, S., D. Pavičić-Hamer \& Č. Lucu. 2004. Seasonal variations of arsenic in mussels Mytilus galloprovincialis. Helgol. Mar. Res., 58: 216-220.

Lazareth, C.E., E. Vander Putten, L. André \& F. Dehairs. 2003. High-resolution trace element profiles in shells of the mongrove bivalve Isognomon ephippium: a record of environmental spatio-temporal variations? Estuarine, Coastal and Shelf Science, 57: 1103-1114.

Lee, B.G., Lee, J.S \& S.N. Luoma. 2006. Comparison of selenium bioaccumulation in the clams Corbicula fluminea and Potamocorbula amurensis: a bioenergetic modelling approach. Environ. Toxicol. Chem., 25: 1933-1940.

Lobel, P.B. \& D.A. Wright. 1982. Relationship between body zinc concentration and allometric growth measurements in the mussel Mytilus edulis. Mar. Biol. (Berlin), 66: 145150.

Lobel, P.B., C.D. Bajdik, S.P. Belkhoide, S.E. Jackson \& H.P. Longerich. 1991. Improved protocol for collecting mussel watch specimens taking into account sex, size, condition, shell shape and chronological age. Arch. Environ. Contam. Toxicol., 21: 409-414.

Markich, S.J. \& R.A. Jeffree. 1994. Absorption of divalent trace metals as analogues of calcium by Australian freshwater bivalves - an explanation of how water hardness re- duces metal toxicity (review). Aquat. Toxicol., 29: 257290.

Maruo, M. \& K.J. Orians. 2006. Determination of complexation in freshwaters of West Canadian lakes by electrochemical analysis. Verh. int. Ver. Limnol., 29: 1481-1486.

Merlini, M., F. Girardi, R. Pietra \& A. Brazzelli. 1965. The stable manganese content of molluscs from Lake Maggiore determined by activation analysis. Limnol. Ocean$o g r .$, 10: 371-378.

Metcalfe-Smith, J.L., J.C. Merriman \& S.P. Batchelor. 1992. Relationships between concentrations of metals in sediment and two species of freshwater mussels in the Ottawa River. Water Poll. Res. J. Canada, 27: 845-869.

Muntau, H. 1981. Analytische Studien zum physicochemischen Status verschiedener Schaermetalle in Oberflächenwässern. Mem. Ist. ital. Idrobiol., 38: 423-461.

Mutvei, H. \& T. Westermark. 2001. How environmental information can be obtained from Naiad shells. In: G. Bauer \& K. Wachtler (Eds), Ecology and evolution of the freshwater mussels Unionida. Ecological Studies, 145. Springer Verlag, Berlin: 367-379.

Oertel, N. 1998. Molluscs as biomonitors of heavy metals in a side-arm system of the River Danube disturbed by engineering activities. Verh. int. Ver. Limnol., 26: 2120-2124.

Patzner, R.A. \& D. Müller. 2001. Effects of eutrophication on Unionids. In: G. Bauer \& K. Watchtler (Eds), Ecology and evolution of freshwater mussels Unionoida. SpringerVerlag, Berlin. Ecological Studies, 145: 327-335.

Price, G.D. \& N.J.G. Pearce. 1997. Biomonitoring of pollution by Cerastoderma edule from the British Isles: a laser ablation ICP-MS study. Mar. Pollut. Bull., 34: 125-131.

Ravera, O. 2004. Importance and difficulties of research on the metal speciation in the aquatic ecosystem: an ecologist's viewpoint. Annali di Chimica, 94: 495-504.

Ravera, O. \& L. Vido. 1961. Misura del Mn-54 in popolazioni di Unio pictorum, L. (Molluschi Lamellibranchi) del Lago Maggiore. Mem. Ist. ital. Idrobiol., 13: 75-84.

Ravera, O., R. Cenci, G.M. Beone, M. Dantas \& P. Lodigiani. 2003a. Trace element concentrations in freshwater mussels and macrophytes as related to those in their environment. J. Limnol., 62: 61-70.

Ravera, O., G.M. Beone, Cenci, R. \& P. Lodigiani. 2003 b. Metal concentrations in Unio pictorum mancus (Mollusca, Lamellibranchia) from 12 Northern Italian lakes in relation to their trophic level. J. Limnol., 62: 121-138.

Ravera, O., A. Frediani, \& N. Riccardi. 2007. Seasonal variations in population dynamics and biomass of two Unio pictorum mancus (Mollusca, Unionidae) populations from two lakes of different trophic state. J. Limnol., 66(1): 1527.

Savari, A., A.P.M. Lockwood \& M. Sheader. 1991. Effects of season and size (age) on the heavy metal concentrations of the common cockle (Cerastoderma edule, L.) from Southampton water. J. Moll. Stud., 57: 45-57. 